\title{
Transfer of Gottschelia grollei, G. patoniae and Scaphophyllum speciosum to Solenostoma based on chloroplast DNA $r b c \mathrm{~L}$ sequences
}

\author{
K. Feldberg $\cdot$ J. Hentschel $\cdot$ A. Bombosch $\cdot$ \\ D. G. Long $\cdot$ J. Váňa $\cdot$ J. Heinrichs
}

Received: 24 March 2009/Accepted: 11 May 2009/Published online: 3 June 2009

(C) The Author(s) 2009. This article is published with open access at Springerlink.com

\begin{abstract}
Maximum parsimony and Bayesian analyses of a chloroplast DNA $r b c \mathrm{~L}$ dataset indicate a position of Gottschelia schizopleura in Scapaniaceae (Jungermanniales suborder Cephaloziineae). Gottschelia grollei, G. patoniae and Scaphophyllum speciosum are nested in Solenostoma (Solenostomataceae, Jungermanniales suborder Jungermanniideae) and are transferred to this genus. Accessions of G. schizopleura from Africa and Asia are separated by long branches.
\end{abstract}

Keywords Cryptic speciation - Gottschelia . Jungermanniales · Molecular phylogeny $\cdot$ Scaphophyllum . Solenostoma $\cdot r b c \mathrm{~L}$

\section{Introduction}

Molecular phylogenetic studies have substantiated the position of liverworts (Marchantiophyta) as the earliest diverging extant main lineage of land plants (Qiu et al.

\footnotetext{
K. Feldberg · J. Hentschel · A. Bombosch · J. Heinrichs ( $\square)$ Department of Systematic Botany, Albrecht von Haller Institute of Plant Sciences, Georg August University, Göttingen, Untere Karspüle 2, 37073 Göttingen, Germany e-mail: jheinri@uni-goettingen.de

\section{J. Hentschel}

Department of Systematic Botany, University of Jena, Jena, Germany

D. G. Long

Royal Botanic Garden, Edinburgh EH3 5LR, UK

J. Váňa

Department of Botany, Charles University,

Praha, Czech Republic
}

2006) and provided numerous new insights into their classification (Crandall-Stotler et al. 2009). The leafy liverworts represent a derived lineage that basically splits into two main clades assigned to as Jungermanniales and Porellales (Heinrichs et al. 2005, 2007; He-Nygrén et al. 2006). Molecular data allowed for a subdivision of Jungermanniales into four suborders (He-Nygrén et al. 2006) and pointed at numerous incongruences of morphologybased classification schemes and topologies derived from DNA sequence evidence (Heinrichs et al. 2004; Hentschel et al. 2006, 2007a; De Roo et al. 2007; Hendry et al. 2007; Vilnet et al. 2008). Schill et al. (2004) demonstrated that the family Lophoziaceae is nested in Scapaniaceae. Heinrichs et al. (2005) formalized the synonymy of Lophoziaceae and Scapaniaceae and showed that Lophoziaceae subfam. Jamesonielloideae (Inoue 1966) forms a separate lineage. Subsequently, this subfamily was included in Adelanthaceae (Heinrichs et al. 2007) or treated as a family of its own (He-Nygrén et al. 2006).

In the framework of a study on the molecular phylogeny of Adelanthaceae s. 1. (Feldberg et al., unpublished), we produced chloroplast DNA $r b c \mathrm{~L}$ sequences of several genera that earlier were assigned to Lophoziaceae subfam. Jamesonielloideae or related clades (Horikawa 1934; Schuster 2002; Long and Váňa 2007). Here we present our results with regard to the genera Gottschelia Grolle and Scaphophyllum Inoue. Gottschelia was set up to include two species with a jungermannialean habit that have exceedingly elongated, cylindrical perianths with the female bracts not accompanied by a bracteole, and slenderly ellipsoidal to cylindrical capsules with linear valves, and angular-stellate gemmae (Grolle 1968; Schuster 2002). Grolle et al. (2003) and Long and Váňa (2007) added two further species that have broadly ellipsoid to ellipsoid-cylindric perianths and do not produce gemmae. Scaphophyllum includes a 
single species with canoe-shaped, strongly concave leaves (Schuster 1998).

\section{Materials and methods}

DNA extraction, PCR amplification and sequencing

DNA extraction, PCR amplification and sequencing were carried out as described in Hentschel et al. (2006). If no product was detected, a second (nested) PCR was performed using the forward primer $r b c \mathrm{~L}-210-\mathrm{F}$ and the reverse primer $r b c \mathrm{~L}-1200-\mathrm{R}$ (Gradstein et al. 2006).

Taxon sampling and phylogenetic analyses

Nineteen new sequences of the genera Adelanthus Mitt., Gottschelia, Scaphophyllum, Syzygiella Spruce and Wettsteinia Schiffn. were generated. The new $r b c \mathrm{~L}$ sequences were compared with GenBank sequences using the BLASTN program (Altschul et al. 1990) and incorporated into a large alignment of $r b c \mathrm{~L}$ sequences of various taxa of Jungermanniopsida. The BLAST searches and preliminary maximum parsimony (MP) analyses of the Jungermanniopsida dataset (results not shown) indicated an affiliation of the new sequences to either Jungermanniales suborder Cephaloziineae or Jungermanniineae sensu He-Nygrén et al. (2006). Further sequences of representatives of these suborders were sampled based on the results of Hentschel et al. (2007a). Representatives of Jungermanniales suborder Lophocoleineae [Bazzania Gray, Chiloscyphus Corda, Mastigophora Nees, Plagiochila (Dumort.) Dumort., He-Nygrén et al. 2006] were chosen as outgroups.

The sequences (Table 1) were manually aligned in BioEdit version 5.09 (Hall 1999) resulting in a dataset including 1.053 homologous sites. Missing parts of sequences were coded as "N" (A, C, G or T). Phylogenetic trees were inferred using maximum parsimony as implemented in PAUP* version 4.0b10 (Swofford 2000). MP analyses were performed with the following options implemented: heuristic search mode with 1,000 randomaddition sequence replicates, tree bisection-reconnection branch swapping (TBR), MULTrees option on, and collapse zero-length branches off. All characters were treated as equally weighted and unordered. Bootstrap support (BS) values were estimated by calculating 1,000 bootstrap replicates (Felsenstein 1985), each with 10 random-additionsequence replicates, TBR branch swapping, and MULTrees on. Rearrangements were limited to 10 million per replicate. Bootstrap percentage values above 70 were regarded as good support (Hillis and Bull 1993). Bayesian inference of phylogeny was conducted using a general time reversible model (GTR) as implemented in MrBayes version
3.1.2 (Huelsenbeck and Ronquist 2001). A Bayesian search was carried out using four simultaneous Markov chains, 5 million generations and sampling every 100th generation. The software tool Tracer version 1.3 (Rambaut and Drummond 2003) was used to examine the parameters and determine the number of trees needed to reach stationarity (burn-in). Bayesian posterior probability (BPP) confidence values were generated from trees found after this initial burn-in period. Bayesian clade credibility values were regarded as significant when exceeding $\mathrm{BPP} \geq 0.95$ (Larget and Simon 1999).

\section{Results}

Three hundred and eight of the 1,053 aligned characters were parsimony informative, 90 autapomorphic and 655 constant. The strict consensus of 432 maximally parsimonious trees (length 1,659 steps, consistency index excluding uninformative characters 0,29 ) is depicted in Fig. 1. Bayesian searches sampled 45,001 trees (mean $\ln =$ -9.465955). The Bayesian topology (Fig. 2) is largely congruent with the MP topology. The ingroup is divided into Cephaloziineae (BS 76, BPP 1.00) and Jungermanniineae (BS 52, BPP 1.00). Seven accessions of the generitype Gottschelia schizopleura (Spruce) Grolle form a monophyletic lineage (BS 100, BPP 1.00) that is placed sister to Chaetophyllopsis whiteleggei (Carrington and Pearson) R. M. Schust. (BS 96, BPP 1.00). Asian and African accessions of G. schizopleura are separated by a deep split (Fig. 2). The G. schizopleura/Chaetophyllopsis clade is placed sister to a clade with representatives of Scapaniaceae (Cephaloziineae) (BS 98, BPP 1.00). Two accessions of Gottschelia patoniae Grolle, Schill and D. G. Long and three accessions of Scaphophyllum speciosum (Horik.) Inoue form monophyletic lineages within the Solenostoma Mitt. clade (Jungermanniineae) (BS 77, BPP 1.00). An accession (type material) of Gottschelia grollei D. G. Long and Váňa is placed sister to Solenostoma sphaerocarpum (Hook.) Steph.

Based on the molecular topologies, we propose a transfer of G. grollei, G. patoniae, and S. speciosum to Solenostoma:

Solenostoma grollei (D. G. Long and Váňa) K. Feldberg, J. Hentschel, A. Bombosch, D. G. Long, Váňa and J. Heinrichs, comb. nov. Bas.: Gottschelia grollei D. G. Long and Váňa, J. Bryol. 29: 167. 2007.

Solenostoma patoniae (Grolle, Schill and D. G. Long) K. Feldberg, J. Hentschel, A. Bombosch, D. G. Long, Váňa and J. Heinrichs, comb. nov. Bas.: Gottschelia patoniae Grolle, Schill and D. G. Long, J. Bryol. 25: 3. 2003.

Solenostoma speciosum (Horik.) J. Hentschel, K. Feldberg, A. Bombosch, D. G. Long, Váňa and J. Heinrichs, 
Table 1 Taxa used in the present study, including information about the origin of the studied material, voucher information and the herbaria where the vouchers are deposited, as well as GenBank accession numbers

\begin{tabular}{|c|c|c|c|}
\hline Taxon & Origin & Voucher & $\begin{array}{l}\text { Accession } \\
\text { number }\end{array}$ \\
\hline Adelanthus decipiens (Hook.) Mitt. & St. Helena & Wigginton $05 / 613$ (GOET) & FJ984934 \\
\hline Adelanthus lindenbergianus (Lehm.) Mitt. & Argentina & Long 31828 (GOET) & FJ984933 \\
\hline Anthelia julacea (L.) Dumort. & Nepal & Long $31292(\mathrm{H})$ & DQ026581 \\
\hline Balantiopsis diplophylla (Hook.f. and Taylor) Mitt. & New Zealand & Engel 20853 (GOET) & DQ312476 \\
\hline Barbilophozia barbata (Schreb.) Loeske & Bulgaria & Hentschel Bryo 0753 (GOET) & DQ312477 \\
\hline Bazzania tricrenata (L.) Gray & Austria & Heinrichs 4388 (GOET) & AY699990 \\
\hline Calypogeia cordifolia Steph. & Japan & Ohnishi 5523 (HIRO) & EF503673 \\
\hline Calypogeia muelleriana (Schiffn.) Müll.Frib. & Germany & Hentschel Bryo 01340 (GOET) & AM392302 \\
\hline Cephalozia bicuspidata (L.) Dumort. & Germany & Hentschel Bryo 0362 (GOET) & AM392307 \\
\hline Cephaloziella divaricata (Sm.) Schiffn. & Germany & Hentschel Bryo 01159 (GOET) & DQ312481 \\
\hline Chaetophyllopsis whiteleggei(Carrington and Pearson) Hamlin & Australia & Curnow $4804(\mathrm{H})$ & AY462292 \\
\hline Chiloscyphus polyanthos (L.) Corda & Finland & He-Nygrén and Piippo 1469 (H) & AY149851 \\
\hline Cylindrocolea recurvifolia (Steph.) Inoue & Japan & Deguchi 36641 (HIRO) & AM392306 \\
\hline Diplophyllum albicans (L.) Dumort. & Germany & Hentschel Bryo 0240 (GOET) & AM392309 \\
\hline Geocalyx graveolens (Schrad.) Nees & Germany & Meinunger s. n. (JE) & DQ312490 \\
\hline Gongylanthus ericetorum (Raddi) Nees & Greece & Düll 63. (35.) (GOET) & AM392303 \\
\hline Gottschelia schizopleura (Spruce) Grolle (1) & Réunion & Schäfer-Verwimp et al. 19823 (GOET) & FJ984938 \\
\hline Gottschelia schizopleura (2) & Réunion & Gradstein 12032 (GOET) & FJ984939 \\
\hline Gottschelia schizopleura (3) & Madagascar & Ah-Peng R96 (GOET) & FJ984940 a \\
\hline Gottschelia schizopleura (4) & Indonesia & Gradstein 12065 (GOET) & FJ984941 ${ }^{\mathrm{a}}$ \\
\hline Gottschelia schizopleura (5) & Indonesia & Gradstein 12064 (GOET) & FJ984942 ${ }^{\mathrm{a}}$ \\
\hline Gottschelia schizopleura (6) & Sri Lanka & Schäfer-Verwimp et al. 5488/II (GOET) & FJ984943 ${ }^{\mathrm{a}}$ \\
\hline Gottschelia schizopleura (7) & Malaysia & Schäfer-Verwimp et al. 18695 (GOET) & FJ984944a \\
\hline Gyrothyra underwoodiana M.Howe & Canada & Hong 98-558 (MO-5241752) & DQ026584 \\
\hline Harpanthus flotovianus (Nees) Nees & Austria & Heinrichs et al. 4390 (GOET) & DQ312492 \\
\hline Isotachis lyallii Mitt. & New Zealand & Engel $21825(\mathrm{~F})$ & AY608032 \\
\hline Jackiella curvata Allison and E.A. Hodgs. & New Zealand & Qiu et al. NZ-03064 (AK) & DQ787461 \\
\hline Jamesoniella autumnalis (DC.) Steph. & China & Koponen et al. $55912(\mathrm{H})$ & AY462303 \\
\hline Jamesoniella rubricaulis (Nees) Grolle & Ecuador & Sauer MS-E 251 (GOET) & GQ120508 \\
\hline Jamesoniella undata (Mont.) Steph. & Bolivia & Churchill et al. 22807 (GOET) & AM392305 \\
\hline Jungermannia atrovirens Dumort. & Germany & Hentschel Bryo 01784 (GOET) & EF503675 \\
\hline Jungermannia pumila Whit. & Russia & Bakalin P-72-2-05 (GOET) & EF503677 \\
\hline Leiocolea collaris (Nees) Jörg. & Slovakia & Hentschel Bryo 0864 (GOET) & DQ312501 \\
\hline Liochlaena lanceolata Nees & USA & Stotler and Crandall-Stotler 107 (ABSH) & AY507409 \\
\hline Liochlaena subulata (A.Evans) Schljakov & Japan & Inoue BSE 859 (GOET) & EF503678 \\
\hline Marsupella emarginata (Ehrh.) Dumort. & Germany & Hentschel Bryo 01638 (GOET) & DQ312505 \\
\hline Mastigophora diclados (F.Weber) Nees & Indonesia & Schäfer-Verwimp and Verwimp 24898 (GOET) & EF503679 \\
\hline Nardia compressa (Hook.) Gray & Belgium & Heinrichs et al. 3806 (GOET) & DQ312507 \\
\hline Nardia geoscyphus (De Not.) Lindb. & Germany & Hentschel Bryo 01874 (GOET) & EF503680 \\
\hline Nardia scalaris Gray & Germany & Hentschel and Wilson Bryo 01618 (GOET) & DQ312508 \\
\hline Nardia succulenta (Lehm. and Lindenb.) Spruce & Bolivia & Churchill et al. 22796 (GOET) & EF503681 \\
\hline Neesioscyphus argillaceus (Nees) Grolle & Brazil & Schäfer-Verwimp and Verwimp 11107 (GOET) & DQ312509 \\
\hline Notoscyphus lutescens (Lehm. and Lindenb.) Mitt. & Vietnam & Pócs et al. 98101/D (GOET) & EF503682 \\
\hline Nowellia curvifolia (Dicks.) Mitt. & Mexico & Burghardt 4493 (GOET) & DQ312510 \\
\hline Pedinophyllum truncatum Inoue & China & Koponen 46768 & AY149855 \\
\hline Plagiochila porelloides (Nees) Lindenb. & Germany & Heinrichs and Groth 4340 (GOET) & AY699998 \\
\hline Saccogyna viticulosa (L.) Dumort. & Tenerife & Gradstein 9977 (GOET) & DQ312514 \\
\hline
\end{tabular}


Table 1 continued

\begin{tabular}{|c|c|c|c|}
\hline Taxon & Origin & Voucher & $\begin{array}{l}\text { Accession } \\
\text { number }\end{array}$ \\
\hline Scapania aspera $\mathrm{M}$. Bernet and Bernet & Bulgaria & Hentschel Bryo 0762 (GOET) & AM392310 \\
\hline Sphenolobus minutus (Schreb.) Berggr. & Spitsbergen & Hentschel Bryo 0421 (GOET) & DQ312475 \\
\hline Solenostoma callithrix (Lindenb. and Gottsche) Steph. & Mexico & Burghardt 4509 (GOET) & DQ312497 \\
\hline Solenostoma crenulatum Mitt. & Belgium & Heinrichs et al. JH 3822 (GOET) & EF503684 \\
\hline Solenostoma grollei (D.G. Long and Váňa) K. Feldberg et al. & China & Long 35715 (GOET) & FJ984948 \\
\hline Solenostoma hyalinum (Lyell) Mitt. & $?$ & Qiu 01041 (MICH) & DQ645970 \\
\hline Solenostoma infuscum (Mitt.) J. Hentschel & Japan & Deguchi s. n. (GOET) & DQ312498 \\
\hline Solenostoma obovatum (Nees) C. Massal. & Austria & Heinrichs et al. 4391 (GOET) & DQ312499 \\
\hline Solenostoma patoniae (Grolle et al.) K. Feldberg et al.(1) & China & Long 34886 (GOET) & FJ984946 ${ }^{\mathrm{a}}$ \\
\hline Solenostoma patoniae (2) & China & Long 37161 (GOET) & FJ984947 \\
\hline $\begin{array}{l}\text { Solenostoma speciosum subsp. villosum (R.M. Schust.) } \\
\text { J. Hentschel et al. (1) }\end{array}$ & China & Long 34713 (GOET) & FJ984949 \\
\hline Solenostoma speciosum subsp. villosum (2) & Bhutan & Miehe 00-444-08-A (GOET) & FJ984950a \\
\hline Solenostoma speciosum subsp. villosum (3) & Bhutan & Miehe 00-444-08-B (GOET) & FJ984951 ${ }^{\mathrm{a}}$ \\
\hline Solenostoma sphaerocarpum (Hook.) Steph. & Germany & Hentschel and Wilson Bryo 01594 (GOET) & EF503686 \\
\hline Syzygiella concreta (Gottsche) Spruce & Bolivia & Churchill 22744 (GOET) & AM392304 \\
\hline Syzygiella liberata Inoue & Bolivia & Churchill 22577 (GOET) & FJ984936 ${ }^{\mathrm{a}}$ \\
\hline Syzygiella ovalifolia Inoue & Sulawesi & Gradstein $11025 \mathrm{c}$ (GOET) & FJ984937 \\
\hline Tylimanthus saccatus (Hook.) Mitt. & & $\begin{array}{l}\text { Qiu 02044; W. Frey and T. Pfeiffer } \\
\text { 98-Mo } 41 \text { A (BSB) }\end{array}$ & DQ645975 \\
\hline Tylimanthus laxus (Lindenb.) Steph. & Ecuador & Gradstein and Mandl 10147 (GOET) & DQ312515 \\
\hline Wettsteinia inversa (Sande Lac.) Mitt. & Sulawesi & Gradstein 11014 (GOET) & FJ984935 ${ }^{\mathrm{a}}$ \\
\hline
\end{tabular}

Herbarium acronyms follow Holmgren et al. (1990)

${ }^{a}$ Accession numbers of newly generated sequences

comb. nov. Bas.: Anastrophyllum speciosum Horik., J. Sci. Hiroshima Univ., Ser. B, Div. 2, Bot. 2: 147. 1934.

Solenostoma speciosum subsp. villosum (R. M. Schust.) J. Hentschel, K. Feldberg, A. Bombosch, D. G. Long, Váňa and J. Heinrichs, comb. nov. Bas.: Scaphophyllum speciosum subsp. villosum R. M. Schust., Bryologist 101: 434. 1998.

\section{Discussion}

The recent progress in liverwort phylogeny is reflected in the new liverwort classification of Crandall-Stotler et al. (2009). However, several genera have not yet been sequenced or been tested for their monophyly. Therefore we anticipate that modifications of the current classification will prove to be necessary to arrive at a natural subdivision.

Several recent molecular phylogenetic studies demonstrated that genus concepts need to be modified both in Scapaniaceae (De Roo et al. 2007; Vilnet et al. 2008) and Adelanthaceae s. 1. (De Roo et al. 2007; He-Nygrén et al. 2006). Recent molecular work also demonstrated the need for modified family concepts in Jungermanniineae (Hentschel et al. 2007a). The present study adds to growing evidence that many current genus concepts do not reflect ancestral relationships within these clades. Accessions of three species currently assigned to Gottschelia (Long and Váňa 2007) are placed in two different suborders of Jungermanniales, Cephaloziineae (G. schizopleura) and Jungermanniineae (G. grollei, G. patoniae). The generitype G. schizopleura is resolved in Scapaniaceae (including Lophoziaceae, Heinrichs et al. 2005) as suggested by earlier authors (Grolle et al. 2003; Long and Váňa 2007). This position is supported by the stellate gemmae, and the longcylindrical, slender perianth with a plicate, crenulatedentate mouth (Grolle 1968). G. grollei and G. patoniae lack gemmae and are provided with broadly ellipsoid to ellipsoid-cylindric perianths (Long and Váňa 2007). These characters link the two species with Solenostoma. The concave, unlobed leaves with rough cuticle are also known from some representatives of Solenostoma (Váňa 1973, 1974). Based on the outcome of the molecular phylogenetic analyses and the morphological similarities, we transfer G. grollei and G. patoniae to Solenostoma. Attempts to 


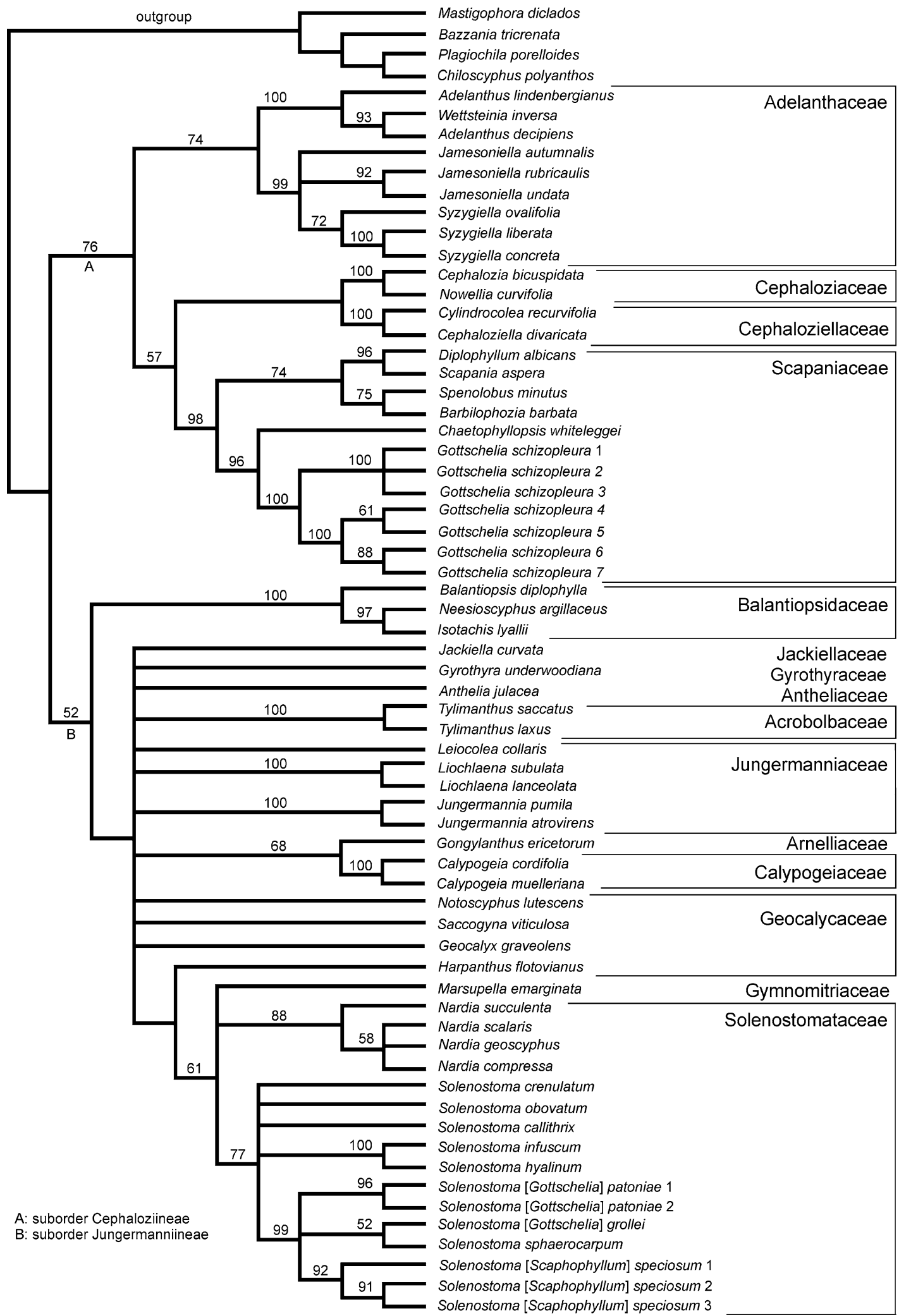

Fig. 1 Strict consensus of the 432 most parsimonious trees recovered during 1,000 random-taxon-addition heuristic searches of the $r b c \mathrm{~L}$ data set. Bootstrap support is indicated at branches. The family classification is based on Heinrichs et al. (2007, Adelanthaceae), Hentschel et al. (2007a, Jungermanniaceae) and Crandall-Stotler et al. (2009) 


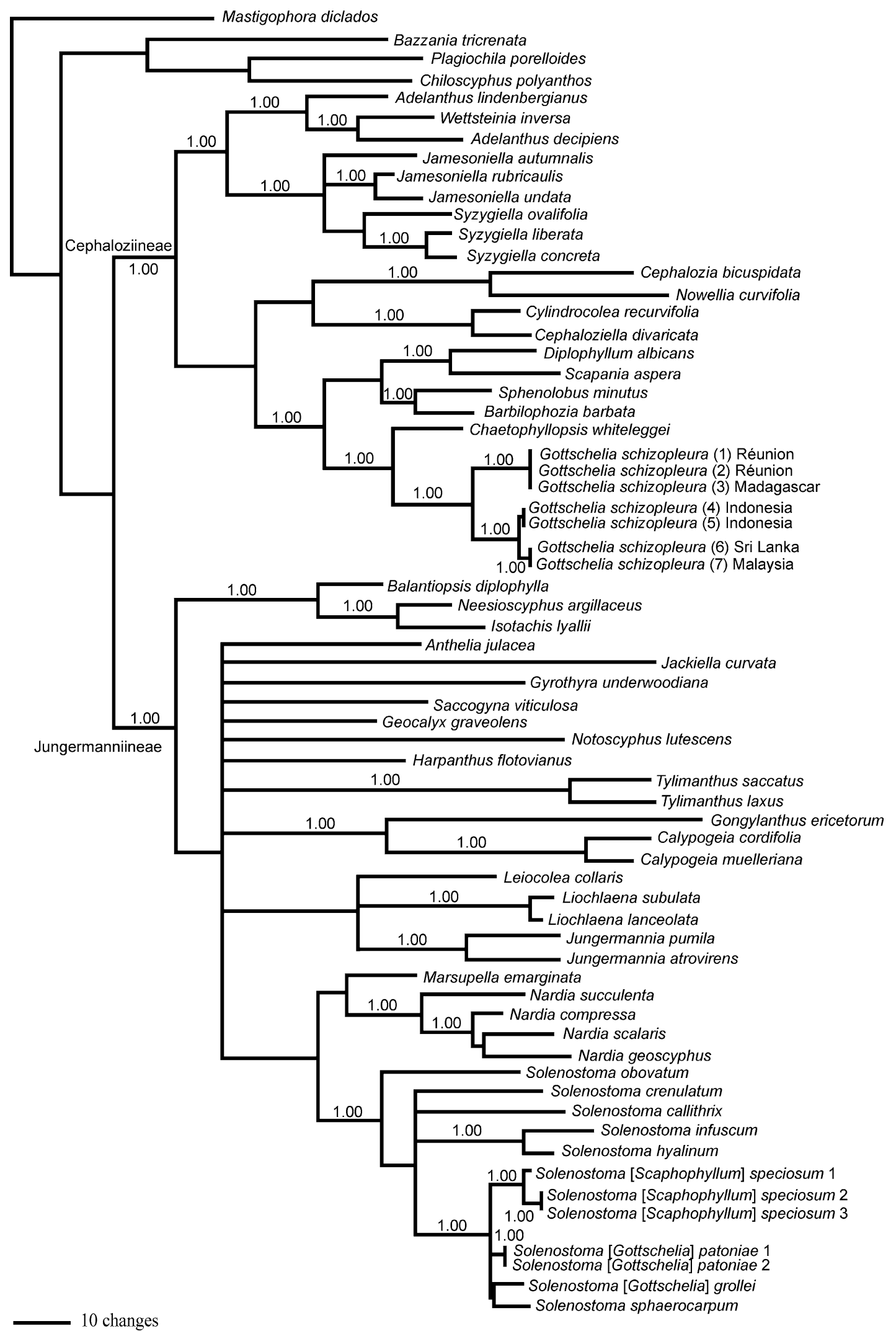

Fig. 2 Majority-rule consensus tree of trees recovered in stationary phase of Bayesian search. Bayesian posterior probabilities ( $\geq 0.95)$ are indicated at branches 
sequence the fourth Gottschelia species, G. maxima (Steph.) Grolle (Long and Váňa 2007), remained unsuccessful. This species [epitype, designated by Grolle et al. (2003: 6), JE!] closely resembles G. schizopleura but differs in the crenulate-dentate leaf margins. Judging from morphology, it can remain in Gottschelia.

The monospecific genus Scaphophyllum (Schuster 1998) differs from Gottschelia and Solenostoma by canoeshaped, strongly concave leaves, and a loosely to densely ciliate stem surface. Based on these differences, Schuster $(1998,2002)$ placed Scaphophyllum in its own subfamily, Scaphophylloideae. However, already Váňa (1973) pointed at striking similarities of Scaphophyllum and several species of Jungermannia L. s. 1. that are now placed in Solenostoma. The present study supports Váňa's (1973) view: Scaphophyllum is nested in a robust subclade of Solenostoma. Based on the molecular topologies (Figs. 1,2) and the morphological similarities of Scaphophyllum and Solenostoma, we transfer Scaphophyllum to the latter genus.

The African and Asian accessions of G. schizopleura are separated by long branches (Fig. 2), indicating a considerable period of isolation of the respective populations. Genetic variation within morphologically circumscribed liverwort species seems to be a common phenomenon and has been observed for several clades, e.g., Bryopteris (Nees) Lindb. (Hartmann et al. 2006), Frullania Raddi (Hentschel et al. 2009), Herbertus Gray (Feldberg et al. 2007), Porella L. (Hentschel et al. 2007b) and Ptychanthus Nees (Ahonen et al. 2005). In many cases, the phylogenetic structure follows a geographical pattern and could be indicative of cryptic speciation (Heinrichs et al. 2009). The Madagascan and Réunion accessions of G. schizopleura are more robust than the accessions from Indonesia, Malaysia and Sri Lanka. A detailed morphological investigation could possibly reveal morphological characters that would allow for a separation of the main clades of G. schizopleura. The type of G. schizopleura originates from Madagascar (Spruce 1885). Grolle (1968, 1971) lowered several (Austral-)asian taxa to synonyms of G. schizopleura. If two species are actually at hand, the basionym Jungermannia colorata $\delta$ microphylla Nees should be picked up to name the Asian populations.

\footnotetext{
Acknowledgements We thank Frank H. Hellwig, Jochen Müller and Hans-Joachim Zündorf of the Herbarium Haussknecht, Jena (JE), for the loan of specimens and the permission to extract DNA. Martin J. Wigginton (Peterborough) kindly provided specimens from St. Helena. This study was supported by the German Research Foundation (DFG Grant HE 3584/4).
}

Open Access This article is distributed under the terms of the Creative Commons Attribution Noncommercial License which permits any noncommercial use, distribution, and reproduction in any medium, provided the original author(s) and source are credited.

\section{References}

Ahonen I, Sass-Gyarmati A, Pócs A (2005) Molecular, morphological and taxonomic evaluation of the Ptychanthus striatus (Lejeuneaceae, Marchantiophyta) complex. Acta Bot Hungarica 47:225-246

Altschul SF, Gish W, Miller W, Myers EW, Lipman DJ (1990) Basic local alignment search tool. J Mol Biol 215:403-410

Crandall-Stotler B, Stotler RE, Long DG (2009) Phylogeny and classification of the Marchantiophyta. Edinb J Bot 66:155-198

De Roo RT, Hedderson TA, Söderström L (2007) Molecular insights into the phylogeny of the leafy liverwort family Lophoziaceae Cavers. Taxon 56:301-314

Feldberg K, Hentschel J, Wilson R, Rycroft DS, Glenny D, Heinrichs J (2007) Phylogenetic biogeography of the leafy liverwort Herbertus (Jungermanniales, Herbertaceae) based on nuclear and chloroplast DNA sequence data: correlation between genetic variation and geographical distribution. J Biogeogr 34:688-698

Felsenstein J (1985) Confidence limits on phylogenies: an approach using the bootstrap. Evolution 39:783-791

Gradstein SR, Wilson R, Ilkiu-Borges AL, Heinrichs J (2006) Phylogenetic relationships and neotenic evolution of Metzgeriopsis (Lejeuneaceae) based on chloroplast DNA sequences and morphology. Bot J Linn Soc 151:293-308

Grolle R (1968) Gottschelia-eine neue Jungermanniales-Gattung der Paläotropis. J Hattori Bot Lab 31:13-19

Grolle R (1971) Jamesoniella und Verwandte. Feddes Repert 82:1-99

Grolle R, Schill DB, Long DG (2003) Notes on Gottschelia (Jungermanniales, Lophoziaceae), with a description of $G$. patoniae, a new species from the East Himalaya. J Bryol 25:3-6

Hall TA (1999) BioEdit: a user-friendly biological sequence alignment editor and analysis program for Windows 95/98/NT. Nucl Acids Symp Ser 41:95-98

Hartmann FA, Wilson R, Gradstein SR, Schneider H, Heinrichs J (2006) Testing hypotheses on species delimitations and disjunctions in the liverwort Bryopteris (Jungermanniopsida: Lejeuneaceae). Int J Plant Sci 167:1205-1214

Heinrichs J, Lindner M, Pócs T (2004) nrDNA internal transcribed spacer data reveal that Rhodoplagiochila R.M.Schust. (Jungermanniales, Marchantiophyta) is a member of Plagiochila sect. Arrectae Carl. Org Divers Evol 4:109-118

Heinrichs J, Gradstein SR, Wilson R, Schneider H (2005) Towards a natural classification of liverworts based on the chloroplast gene $r b c$ L. Cryptogam Bryol 26:131-150

Heinrichs J, Hentschel J, Wilson R, Feldberg K, Schneider H (2007) Evolution of leafy liverworts (Jungermanniidae, Marchantiophyta): estimating divergence times from chloroplast DNA sequences using penalized likelihood with integrated fossil evidence. Taxon 56:31-44

Heinrichs J, Hentschel J, Feldberg K, Bombosch A, Schneider H (2009) Phylogenetic biogeography and taxonomy of disjunctly distributed bryophytes. J Syst Evol (in press)

Hendry TA, Wang B, Yang Y, Davis EC, Braggins JE, Schuster RM, Qiu YL (2007) Evaluating phylogenetic positions of four liverworts from New Zealand, Neogrollea notabilis, Jackiella curvata, Goebelobryum unguiculatum and Herzogianthus vaginatus, using three chloroplast genes. Bryologist 110:738-751

Hentschel J, Wilson R, Burghardt M, Zündorf H-J, Schneider H, Heinrichs J (2006) Reinstatement of Lophocoleaceae (Jungermanniopsida) based on chloroplast gene $r b c \mathrm{~L}$ data: exploring the importance of female involucres for the systematics of Jungermanniales. Plant Syst Evol 258:125

Hentschel J, Paton JA, Schneider H, Heinrichs J (2007a) Acceptance of Liochlaena Nees and Solenostoma Mitt., the systematic 
position of Eremonotus Pearson and notes on Jungermannia L. s.l. (Jungermanniidae) based on chloroplast DNA sequence data. Plant Syst Evol 268:147-157

Hentschel J, Zhu RL, Long DG, Davison PG, Schneider H, Gradstein SR, Heinrichs J (2007b) A phylogeny of Porella (Porellaceae, Jungermanniopsida) based on nuclear and chloroplast DNA sequences. Mol Phylogenet Evol 45:693-705

Hentschel J, von Konrat MJ, Pócs T, Schäfer-Verwimp A, Shaw AJ, Schneider H, Heinrichs J (2009) Molecular insights into the phylogeny and subgeneric classification of Frullania Raddi (Frullaniaceae, Porellales). Molec Phylogen Evol 52:142-156

He-Nygrén X, Juslén A, Ahonen I, Glenny D, Piippo S (2006) Illuminating the evolutionary history of liverworts (Marchantiophyta) - towards a natural classification. Cladistics 22:1-31

Hillis DM, Bull JJ (1993) An empirical test of bootstrapping as a method for assessing the confidence in phylogenetic analysis. Syst Biol 42:182-192

Holmgren PK, Holmgren NH, Barnett LC (1990) Index herbariorum. Part I: the herbaria of the world (Regnum Veg. 120), 8th edn. New York Botanical Garden, New York

Horikawa Y (1934) Monographia hepaticarum Austral-Japonicarum. J Sci Hiroshima Univ Ser B Div 2(2):101-325

Huelsenbeck JP, Ronquist F (2001) MRBAYES: Bayesian inference of phylogenetic trees. Bioinformatics 17:754-755

Inoue H (1966) A monograph of the hepatic genus Syzygiella Spruce. J Hattori Bot Lab 29:171-213

Larget B, Simon DL (1999) Markov chain Monte Carlo algorithms for the Bayesian analysis of phylogenetic trees. Mol Biol Evol 16:750-759

Long DG, Váňa J (2007) The genus Gottschelia Grolle (Jungermanniopsida, Lophoziaceae) in China, with a description of $G$. grollei, sp. nov. J Bryol 29:165-168
Qiu YL, Li LB, Wang B, Chen ZD, Knoop V, Groth-Malonek M, Dombrovska O, Lee J, Kent L, Rest J, Estabrook GF, Hendry TA, Taylor DW, Testa CM, Ambros M, Crandall-Stotler B, Duff RJ, Stech M, Frey W, Quandt D, Davis CC (2006) The deepest divergences in land plants inferred from phylogenomic evidence. Proc Nat Acad Sci USA 103:15511-15516

Rambaut A, Drummond AJ (2003) Tracer v1.3. http://evolve.zoo.ox. ac.uk

Schill DB, Long DG, Moeller M, Squirrel J (2004) Phylogenetic relationships between Lophoziaceae and Scapaniaceae based on chloroplast sequences. In: Goffinet B, Hollowell V, Magill R (eds) Molecular systematics of bryophytes. Monogr Syst Bot MO Bot Gard 98:141-149

Schuster RM (1998) On the genus Scaphophyllum (Jungermanniaceae). Bryologist 101:428-434

Schuster RM (2002) Austral Hepaticae part II. Nova Hedwigia Beih 119:iii-viii, 1-606

Spruce R (1885) Hepaticae amazonicae et andinae II. Trans Proc Bot Soc Edinb 15:309-589

Swofford DL (2000) PAUP*. Phylogenetic analysis using parsimony (*and other methods). Sinauer Associates, Sunderland

Váňa J (1973) Studien über die Jungermannioideae (Hepaticae) 1. Allgemeine Charakteristik. Folia Geobot Phytotax 8:181-208

Váňa J (1974) Studien über die Jungermannioideae (Hepaticae) 4. Jungermannia subg. Plectocolea und subg. Solenostoma: Allgemeines, süd- und mittelamerikanische Arten. Folia Geobot Phytotax 9:179-208

Vilnet AA, Konstantinova NA, Troitsky AV (2008) Phylogeny and systematics of the genus Lophozia s. str. (Dumort.) Dumort. (Hepaticae) and related taxa from nuclear ITS1-2 and chloroplast trnL-F sequences. Mol Phylogen Evol 47:403-418 